\title{
IMPLEMENTASI PENGOLAHAN MODEL WARNA RGB PADA APLIKASI IDENTIFIKASI WARNA
}

\author{
Asep Nana Hermana1, Andriana Zulkarnain ${ }^{2}$, Yudi Arief Riadi ${ }^{1}$ \\ 1]urusan Teknik Informatika Institut Teknologi Nasional \\ 2Jurusan Teknik Elektro Universitas Langlangbuana \\ asep nana h@yahoo.com, andriana6970@gmail.com, yudi.arief.riadi@gmail.com
}

\begin{abstract}
ABSTRAK
Ada sebagian orang yang memiliki kelainan pada penglihatan, salah satunya adalah kelainan melakukan identifikasi warna (buta warna). Salah satu cara untuk menolong melakukan identifikasi warna yaitu dengan cara menampilkan informasi warna ke dalam teks. Informasi warna video digital masih berbentuk model warna $\mathrm{YCbCr}$. Model warna $\mathrm{YCbCr}$ adalah model warna yang digunakan pada kamera handphone. Metode pengkonversian $\mathrm{YCbCr}$ digunakan untuk mendapatkan dan mengkonversikan nilai warna yang didapat ke dalam model warna RGB. Nilai hasil pengkonversian dibandingkan dengan nilai RGB yang tersimpan pada program dengan menggunakan metode euclidean distance. Metode euclidean distance berfungsi untuk mencari nilai selisih terkecil dari dua matriks yang dibandingkan. Hasil perbandingan ditampilkan sebagai keluaran yang terdiri dari gambar warna, nama warna, nilai warna dan warna yang serupa dengan hasil perbandingan. Berdasarkan hasil pengujian warna objek dapat dideteksi dengan persentase keberhasilan mencapai 93,75\%.
\end{abstract}

Kata Kunci : Warna, RGB, YCbCr, Euclidean Distance

\begin{abstract}
There are some people who have vision abnormalities, one in identifying colors (color blindness). One of the ways to help identify colors is display the information on a color in the text. Digital video color information is still in the $\mathrm{YCbCr}$ color model form. YCbCr color models used on handphone camera. YCbCr conversion method used to obtain and convert the color values from $\mathrm{YCbCr}$ color model to $R G B$ color model. The resulting value compared with the RGB values which stored in the program by using euclidean distance. Euclidean distance method used to find the smallest difference value of the two compared matrices. The comparison is shown as an output consisting of color image, color name, color values and similar color to the results of the comparison. Based on the test results the color of objects can be detected with a success percentage reached $93.75 \%$.
\end{abstract}

\section{Keywords : Color, RGB, YCbCr, Euclidean Distance}




\section{LATAR BELAKANG}

\subsection{Latar Belakang}

Ada sebagian orang yang memiliki kelainan pada penglihatan, salah satunya adalah kelainan melakukan identifikasi warna (buta warna parsial atau total). Salah satu cara untuk menolong melakukan identifikasi warna yaitu menampilkan informasi warna ke dalam teks.

Sistem identifikasi warna diawali dengan menyimpan nama, gambar warna dan nilai warna model warna RGB yang dijadikan sebagai data sample. Cara kerja aplikasi identifikasi warna yaitu mengambil gambar warna dengan kamera handphone, sistem mengolah gambar yang dideteksi dan didapatkan nilai $\mathrm{Y}, \mathrm{U}(\mathrm{Cb})$ dan $\mathrm{V}(\mathrm{Cr}$ ). Informasi warna video digital dalam bentuk model warna YCbCr. Model warna $\mathrm{YCbCr}$ adalah model warna yang digunakan pada kamera handphone. Nilai $\mathrm{YCbCr}$ yang didapat dikonversikan ke dalam model warna RGB dengan menggunakan metode pengkonversian $\mathrm{YCbCr}$ ke RGB. Hasil pengkonversian dibandingkan dengan data sample menggunakan metode euclidean distance. Metode euclidean distance berfungsi untuk mencari nilai terkecil dari selisih dua matriks yang dibandingkan. Nilai hasil perbandingan yang terdiri dari nama warna, gambar warna dan nilai warna ditampilkan kepada pengguna.

\subsection{Rumusan Masalah}

Rumuskan masalah yang dihadapi pada penelitian ini adalah :

1. Bagaimana cara merancang sistem identifikasi warna dengan pengolahan model warna RGB.

2. Bagaimana cara mengkonversi warna yang diambil ke dalam model warna RGB menggunakan metode konversi YCbCr ke RGB.

3. Bagaimana cara membandingkan warna yang diambil dengan warna sample.

\subsection{Tujuan}

Tujuan penelitian ini adalah menerapkan model warna $\mathrm{YCbCr}$ untuk membantu pengguna khususnya yang memiliki kelainan buta warna parsial maupun total dalam mengidentifikasi warna.

\subsection{Batasan Masalah}

Batasan masalah yang ditentukan pada penelitian ini sebagai berikut:

1. Warna yang digunakan sebagai objek adalah warna independen.

2. Keluaran pada sistem ini adalah nama warna, gambar warna, nilai warna dalam RGB, HSV dan heksadesimal. 


\section{METODOLOGI PENELITIAN}

Berikut beberapa tahapan yang disusun sebagai metodologi penelitian ini diantaranya :

\subsection{Rancangan Penelitian}

Excisting Variable dan pengembangan merupakan tipe penelitian yang digunakan dalam penelitian ini. Excisting Variable yaitu penelitian yang dilakukan dengan berdasarkan data yang diperoleh dari buku, jurnal dan artikel sejenis yang telah dilakukan dari penelitian sebelumnya, selanjutnya penelitian pengembangan yaitu mengembangkan dari penelitian yang telah dilakukan sebelumnya (Sugiyono, 2002).

\subsection{Subjek Penelitian}

Enam warna yang dicetak di atas dua media kertas merupakan subjek penelitian pada penelitian perancangan aplikasi identifikasi warna ini, warna yang dideteksi menggunakan tiga spesifikasi kamera yang berbeda dan penggunaan lampu flash yang digunakan untuk menganalisis efektifitas pendeteksian dan parameter yang mempengaruhi hasil pendeteksian. Teknik pengambilan informasi yang digunakan yaitu purpose sampling, dilakukan dengan mengambil subjek penelitian yang memenuhi kriteria. Dimana kriteria tersebut dibuat oleh peneliti sendiri (Nordwood, 2000).

\subsection{Studi Literatur}

Studi ini dilakukan dengan cara mencari sekaligus mempelajari beberapa literatur dan artikel mengenai pengolahan model warna RGB sebagai acuan dalam perencanaan dan pembuatan sistem atau aplikasi

\section{ANALISIS DAN PEMBAHASAN}

\subsection{Analisis dan Perancangan Sistem}

Gambaran umum sistem aplikasi identifikasi warna memiliki lima tahapan seperti yang diilustrasikan pada Gambar 1.

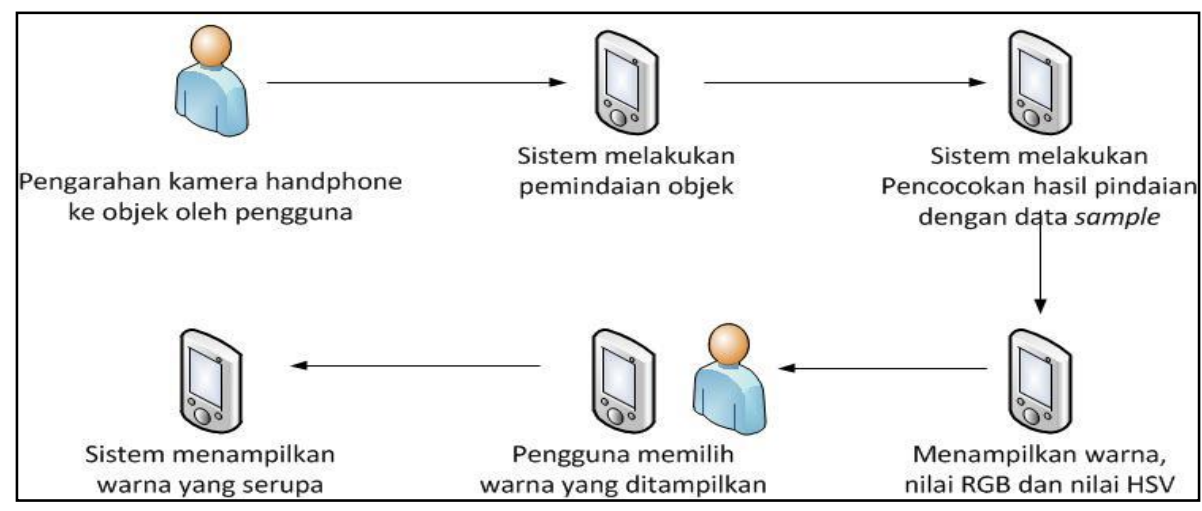

Gambar 1 : Proses Bisnis 
Tahapan-tahapan aplikasi identifikasi warna, yaitu :

1. Pengarahan kamera handphone ke objek.

Proses pengarahan kamera handphone ke objek oleh pengguna diilustrasikan pada Gambar 2.

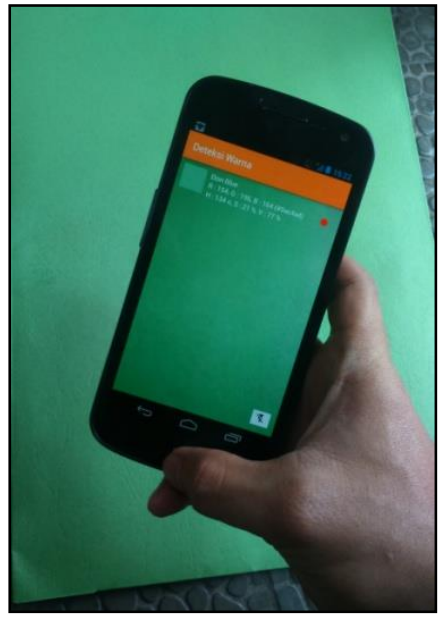

Gambar 2 : Pengarahan Kamera Handphone ke Objek

2. Sistem melakukan pemindaian objek

Sistem melakukan pemindaian objek yang ditangkap kamera untuk mendapatkan informasi nilai warna objek. Informasi nilai warna objek masih berbentuk model warna YCbCr. Nilai warna objek dikonversikan ke dalam bentuk model warna RGB menggunakan metode pengkonversian $\mathrm{YCbCr}$ ke RGB. Proses pengkonversian $\mathrm{YCbCr}$ ke RGB diilustrasikan oleh flowchart Gambar 3.
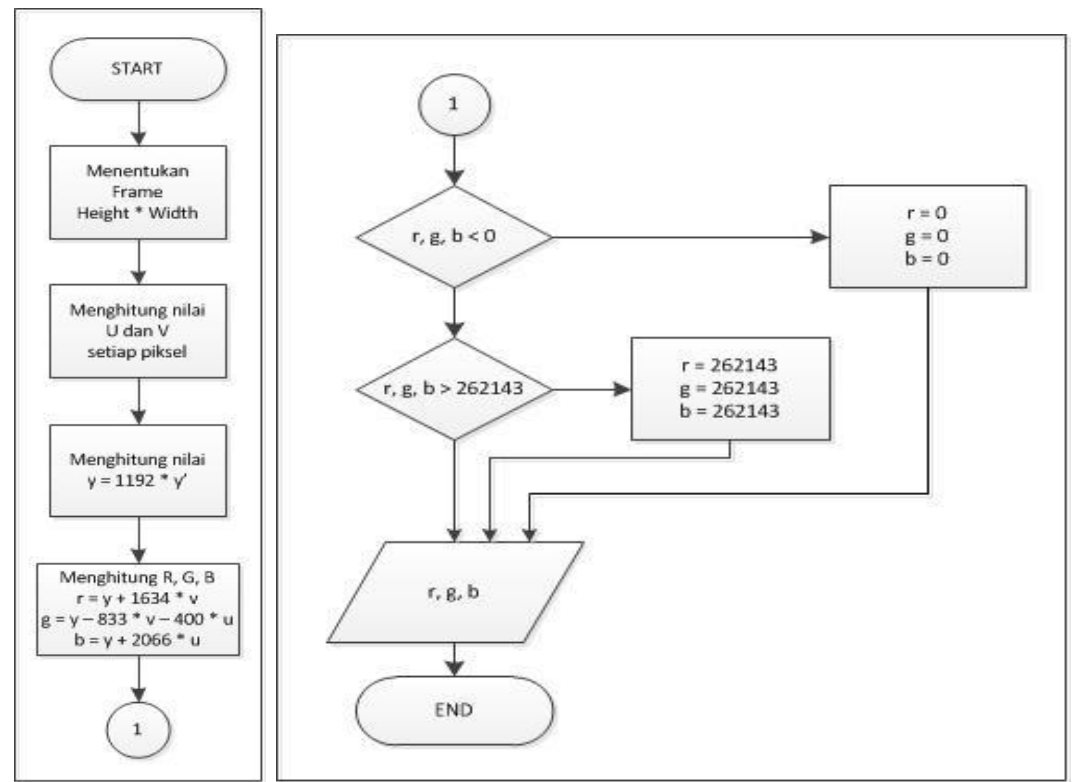

Gambar 3 : Flowchart Konversi YCbCr ke RGB 
Langkah awal dari pengkonversian $\mathrm{YCbCr}$ ke RGB yaitu penentuan luas frame yang dideteksi, frame adalah luas area yang dihitung, luas frame didapatkan dari tinggi frame dikali lebar frame, tinggi frame dihitung dari titik terbawah frame sampai titik teratas frame, lebar frame dihitung dari titik paling kiri dari frame sampai titik paling kanan frame, nilai $\mathrm{U}(\mathrm{Cb})$ dan $\mathrm{V}(\mathrm{Cr})$ pada setiap piksel di dalam frame dihitung, nilai $\mathrm{U}(\mathrm{Cb})$ adalah nilai komponen warna biru dari citra dan nilai $\mathrm{V}(\mathrm{Cr})$ adalah nilai komponen warna merah dari citra, nilai $Y$ dihitung menggunakan rumus $\mathrm{Y}=1192 * \mathrm{Y}^{\prime}$, nilai $\mathrm{Y}^{\prime}$ adalah nilai /uminance dari citra. Nilai $\mathrm{Y}, \mathrm{Cb}$ dan $\mathrm{Cr}$ yang didapat digunakan untuk menghitung dan mendapatkan nilai RGB dari warna objek yang dideteksi.

\section{Contoh kasus :}

Jika diketahui tinggi frame $=1$, lebar frame $=1$, nilai $Y^{\prime}=0$, nilai $U=0$ dan nilai $\mathrm{V}=0$, maka didapatkan :

1. Luas frame $=$ height $*$ width $=1 * 1=1$;

2. Nilai $Y^{\prime}=0, U=0$ dan $\mathrm{V}=0$;

3. Hitung nilai $Y$ dengan rumus $Y=1192 * Y^{\prime}{ }^{[8]}$ didapatkan $Y=1192 * 0=0$;

4. Hitung nilai $R, G$ dan $B$ dengan rumus :

$$
\begin{aligned}
& \mathrm{R}=\mathrm{Y}+1634 * \mathrm{~V} \\
& \mathrm{G}=\mathrm{Y}-833 * \mathrm{~V}-400 * \mathrm{U} \\
& \mathrm{B}=\mathrm{Y}+2066 * \mathrm{U}[8] \\
& \text { didapatkan } \\
& \mathrm{R}=0+1634 * 0=0 ; \\
& \mathrm{G}=0-833 * 0-400 * 0=0 ; \\
& \mathrm{B}=0+2066 * 0=0 ;
\end{aligned}
$$

3. Sistem mencocokan hasil pindaian dengan data sample.

Nilai hasil pemindaian objek yang telah dikonversikan ke dalam model warna RGB dicocokan oleh sistem dengan metode euclidean distance. Metode euclidean distance digunakan dalam mencari selisih nilai terkecil dari dua matriks yang dibandingkan. ${ }^{[9]}$ Rumus metode euclidean distance dapat dilihat pada Gambar 3.

$$
d_{x, y}=\sqrt{\left(x_{1}-y_{1}\right)^{2}+\left(x_{2}-y_{2}\right)^{2}+\left(x_{3}-y_{3}\right)^{2}}
$$

Gambar 3 : Rumus Metode Euclidean Distance

$$
\begin{aligned}
& \text { Keterangan rumus : } d=\text { selisih nilai; } \\
& x=\text { koordinat titik pertama; } \\
& y=\text { koordinat titik kedua. }
\end{aligned}
$$


Nilai RGB yang didapat dari hasil pengkonversian dibandingkan dengan nilai RGB yang tersimpan pada program, dicari selisih dari kedua nilai RGB tersebut menggunakan metode euclidean distance.

Jika nilai $R G B$ yang didapat $R=0, G=0$ dan $B=0$, dan nilai $R G B$ yang tersimpan pada program terdiri dari Black Bean dengan nilai $\mathrm{R}=61, \mathrm{G}=12$ dan $\mathrm{B}=2$, Black Leather Jacket dengan nilai $\mathrm{R}=37, \mathrm{G}=53$ dan $\mathrm{B}=41$. Maka didapatkan nilai selisih sebagai berikut :

$\mathrm{d}_{1}=$ selisih nilai RGB hasil

pemindaian dengan nilai RGB Black

Bean.

$\mathrm{d}_{1}=$

$\sqrt{\left(x_{1}-y_{1}\right)^{2}+\left(x_{2}-y_{2}\right)^{2}+\left(x_{3}-y_{3}\right)^{2}}$

[9]

$\mathrm{d}_{1}=$

$\sqrt{(0-61)^{2}+(0-12)^{2}+(0-2)^{2}}$

$\mathrm{d}_{1}=\sqrt{3721+144+4}$

$\mathrm{d}_{1}=\sqrt{3869}$

$d_{1}=62,2$

$$
\begin{aligned}
\mathrm{d}_{2}= & \text { selisih nilai RGB hasil } \\
& \text { pemindaian dengan nilai RGB } \\
& \text { Black Leather Jacket. }
\end{aligned}
$$

$\mathrm{d}_{2}=$

$\sqrt{\left(x_{1}-y_{1}\right)^{2}+\left(x_{2}-y_{2}\right)^{2}+\left(x_{3}-y_{3}\right)^{2}}$

[9]

$\mathrm{d}_{2}=$

$\sqrt{(0-37)^{2}+(0-53)^{2}+(0-41)^{2}}$

$\mathrm{d}_{2}=\sqrt{1369+2809+1681}$

$\mathrm{d}_{2}=\sqrt{5859}$

$\mathrm{d}_{2}=76,5$

Dari hasil perbandingan $d_{1}$ dan $d_{2}$ didapatkan bahwa nilai selisih $d_{1}$ lebih kecil dari $d_{2}$, maka didapatkan nilai warna pada program yang paling mendekati nilai hasil pemindaian adalah nilai $\mathrm{d}_{1}$, yaitu warna Black Bean.

4. Sistem menampilkan gambar warna, nama warna, nilai warna.

Sistem menampilkan informasi-informasi warna berdasarkan hasil pencocokan yang terdiri dari gambar warna, nama warna dan nilai warna seperti terlihat pada Gambar 4.

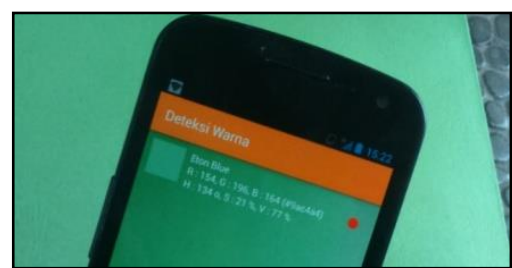

Gambar 4 Rumus Metode Euclidean Distance

5. Pengguna memilih warna yang ditampilkan.

Sistem menampilkan informasi detail warna yang dipilih oleh pengguna. Seperti yang terlihat pada Gambar 5. 


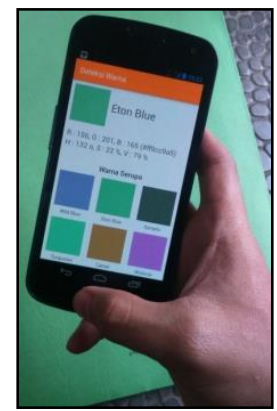

Gambar 5 Informasi detail warna

6. Sistem menampilkan warna serupa.

Sistem menampilkan informasi detail warna serupa yang dipilih oleh pengguna. Seperti yang terlihat pada Gambar 6 .

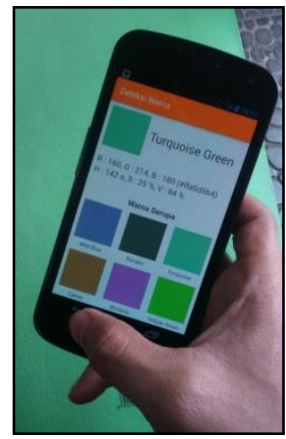

Gambar 6 Informasi detail warna serupa

\subsection{Desain User Interface}

Aplikasi identifikasi warna memiliki enam halaman yang yang terdiri dari halaman menu utama, halaman proses deteksi, halaman detail warna, halaman bantuan dan halaman about yang memiliki desain user interface sebagai berikut :

a. Halaman Menu Utama

Pada halaman menu utama memiliki 3 tombol, yaitu tombol mulai untuk memulai proses pendeteksian warna, tombol bantuan yang menampilkan cara penggunaan aplikasi dan tombol about yang menampilkan identitas pembuat aplikasi.

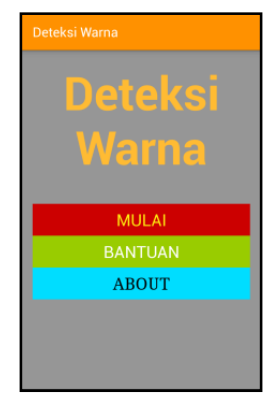

Gambar 7 Halaman Menu Utama.

b. Halaman Proses Deteksi

Pada halaman proses deteksi menampilkan nama warna, gambar warna dan nilai RGB dari warna hasil pendeteksian. Terdapat bulatan di pojok kanan atas 
yang mengindikasikan proses pendeteksian warna, dimana ketika berwarna hijau mengindikasikan sistem melakukan pengidentifikasian dan ketika berwarna merah mengindikasikan sistem sedang stand by. Di pojok kanan bawah terdapat tombol yang berfungsi untuk menghidupkan atau mematikan lampu flash, jika handphone yang digunakan tidak mendukung fitur lampu flash akan muncul notifikasi peringatan.

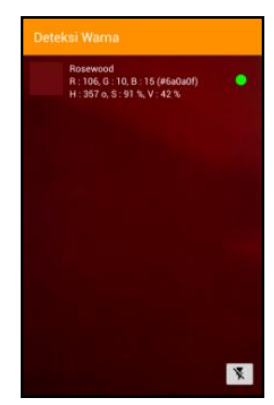

Gambar 8 : Halaman Proses Deteksi

c. Halaman Detail Warna

Pada halaman detail warna menampilkan gambar warna, nama warna, nilai warna dalam bentuk RGB, HSV dan heksadesimal, serta beberapa warna yang memiliki tingkat kemiripan berdasarkan kedekatan nilai RGB.

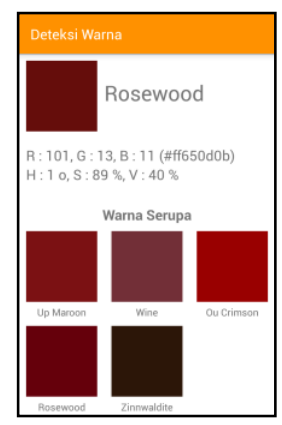

Gambar 9 Halaman Detail Warna

\subsection{Pengujian Sistem}

Pengujian dilakukan dengan cara mencetak enam warna (warna merah, biru, hijau, kuning, hitam dan putih) pada dua media kertas (kertas Houtvrij Schrijfpapier dan Glossy Photo Paper). Yang kemudian dideteksi menggunakan aplikasi identifikasi warna dengan tiga handphone yang memiliki spesifikasi kamera yang berbeda, yaitu 5 Megapiksel, 8 Megapiksel dan 13 Megapiksel. Pengujian dilakukan di dalam ruangan (indoor) dan di luar ruangan (outdoor). Serta dilakukan dengan atau tanpa lampu flash.

\section{Hasil Pengujian}

- Warna yang diuji : Hijau 
Jenis kertas $\quad: \quad$ HVS

\begin{tabular}{|c|c|c|c|c|}
\hline Kamera & $\begin{array}{c}\text { Indoor } \\
\text { Tanpa Flash }\end{array}$ & $\begin{array}{c}\text { Indoor } \\
\text { DenganFlash }\end{array}$ & $\begin{array}{c}\text { Outdoor } \\
\text { Tanpa Flash }\end{array}$ & $\begin{array}{c}\text { Outdoor } \\
\text { Dengan Flash }\end{array}$ \\
\hline 5 Megapiksel & Terdeteksi & Terdeteksi & Terdeteksi & Terdeteksi \\
\hline 8 Megapiksel & Terdeteksi & Terdeteksi & Terdeteksi & Terdeteksi \\
\hline 13 Megapiksel & Terdeteksi & Terdeteksi & Terdeteksi & Terdeteksi \\
\hline
\end{tabular}

- Warna yang diuji : Hijau Jenis kertas

\begin{tabular}{|c|c|c|c|c|}
\hline Kondisi & $\begin{array}{c}\text { Indoor } \\
\text { Tanpa Flash }\end{array}$ & $\begin{array}{c}\text { Indoor } \\
\text { DenganFlash }\end{array}$ & $\begin{array}{c}\text { Outdoor } \\
\text { Tanpa Flash }\end{array}$ & $\begin{array}{c}\text { Outdoor } \\
\text { Dengan Flash }\end{array}$ \\
\hline 5 Megapiksel & Terdeteksi & Tidak Terdeteksi & Terdeteksi & Terdeteksi \\
\hline 8 Megapiksel & Terdeteksi & Terdeteksi & Terdeteksi & Terdeteksi \\
\hline 13 Megapiksel & Terdeteksi & Terdeteksi & Terdeteksi & Terdeteksi \\
\hline
\end{tabular}

- Warna yang diuji : Merah Jenis kertas : HVS

\begin{tabular}{|c|c|c|c|c|}
\hline Kondisi & $\begin{array}{c}\text { Indoor } \\
\text { Tanpa Flash }\end{array}$ & $\begin{array}{c}\text { Indoor } \\
\text { DenganFlash }\end{array}$ & $\begin{array}{c}\text { Outdoor } \\
\text { Tanpa Flash }\end{array}$ & $\begin{array}{c}\text { Outdoor } \\
\text { Dengan Flash }\end{array}$ \\
\hline 5 Megapiksel & Terdeteksi & Terdeteksi & Terdeteksi & Terdeteksi \\
\hline 8 Megapiksel & Terdeteksi & Terdeteksi & Terdeteksi & Terdeteksi \\
\hline 13 Megapiksel & Terdeteksi & Terdeteksi & Terdeteksi & Terdeteksi \\
\hline
\end{tabular}

- Warna yang diuji : Merah Jenis kertas : HVS

\begin{tabular}{|c|c|c|c|c|}
\hline Kamera & $\begin{array}{c}\text { Indoor } \\
\text { Tanpa Flash }\end{array}$ & $\begin{array}{c}\text { Indoor } \\
\text { DenganFlash }\end{array}$ & $\begin{array}{c}\text { Outdoor } \\
\text { Tanpa Flash }\end{array}$ & $\begin{array}{c}\text { Outdoor } \\
\text { Dengan Flash }\end{array}$ \\
\hline 5 Megapiksel & Tidak Terdeteksi & Terdeteksi & Terdeteksi & Terdeteksi \\
\hline 8 Megapiksel & Terdeteksi & Terdeteksi & Terdeteksi & Terdeteksi \\
\hline 13 Megapiksel & Terdeteksi & Terdeteksi & Terdeteksi & Terdeteksi \\
\hline
\end{tabular}

- Warna yang diuji : Biru Jenis kertas : HVS

\begin{tabular}{|c|c|c|c|c|}
\hline Kondisi & $\begin{array}{c}\text { Indoor } \\
\text { Tanpa Flash }\end{array}$ & $\begin{array}{c}\text { Indoor } \\
\text { DenganFlash }\end{array}$ & $\begin{array}{c}\text { Outdoor } \\
\text { Tanpa Flash }\end{array}$ & $\begin{array}{c}\text { Outdoor } \\
\text { Dengan Flash }\end{array}$ \\
\hline 5 Megapiksel & Terdeteksi & Terdeteksi & Terdeteksi & Terdeteksi \\
\hline 8 Megapiksel & Terdeteksi & Terdeteksi & Terdeteksi & Terdeteksi \\
\hline 13 Megapiksel & Terdeteksi & Terdeteksi & Terdeteksi & Terdeteksi \\
\hline
\end{tabular}

- Warna yang diuji : Biru Jenis kertas : Foto 


\begin{tabular}{|c|c|c|c|c|}
\hline Kondisi & $\begin{array}{c}\text { Indoor } \\
\text { Tanpa Flash }\end{array}$ & $\begin{array}{c}\text { Indoor } \\
\text { DenganFlash }\end{array}$ & $\begin{array}{c}\text { Outdoor } \\
\text { Tanpa Flash }\end{array}$ & $\begin{array}{c}\text { Outdoor } \\
\text { Dengan Flash }\end{array}$ \\
\hline 5 Megapiksel & Terdeteksi & Terdeteksi & Terdeteksi & Terdeteksi \\
\hline 8 Megapiksel & Terdeteksi & Terdeteksi & Terdeteksi & Terdeteksi \\
\hline 13 Megapiksel & Terdeteksi & Terdeteksi & Terdeteksi & Terdeteksi \\
\hline
\end{tabular}

- Warna yang diuji : Kuning Jenis kertas : HVS

\begin{tabular}{|c|c|c|c|c|}
\hline Kamera & $\begin{array}{c}\text { Indoor } \\
\text { Tanpa Flash }\end{array}$ & $\begin{array}{c}\text { Indoor } \\
\text { DenganFlash }\end{array}$ & $\begin{array}{c}\text { Outdoor } \\
\text { Tanpa Flash }\end{array}$ & $\begin{array}{c}\text { Outdoor } \\
\text { Dengan Flash }\end{array}$ \\
\hline 5 Megapiksel & Terdeteksi & Terdeteksi & Terdeteksi & Terdeteksi \\
\hline 8 Megapiksel & Terdeteksi & Terdeteksi & Terdeteksi & Terdeteksi \\
\hline 13 Megapiksel & Terdeteksi & Terdeteksi & Terdeteksi & Terdeteksi \\
\hline
\end{tabular}

- Warna yang diuji : Kuning Jenis kertas Foto

\begin{tabular}{|c|c|c|c|c|}
\hline Kondisi & $\begin{array}{c}\text { Indoor } \\
\text { Tanpa Flash }\end{array}$ & $\begin{array}{c}\text { Indoor } \\
\text { DenganFlash }\end{array}$ & $\begin{array}{c}\text { Outdoor } \\
\text { Tanpa Flash }\end{array}$ & $\begin{array}{c}\text { Outdoor } \\
\text { Dengan Flash }\end{array}$ \\
\hline 5 Megapiksel & Terdeteksi & Terdeteksi & Terdeteksi & Terdeteksi \\
\hline 8 Megapiksel & Terdeteksi & Terdeteksi & Terdeteksi & Terdeteksi \\
\hline 13 Megapiksel & Terdeteksi & Terdeteksi & Terdeteksi & Terdeteksi \\
\hline
\end{tabular}

- Warna yang diuji : Hitam Jenis kertas : HVS

\begin{tabular}{|c|c|c|c|c|}
\hline Kondisi & $\begin{array}{c}\text { Indoor } \\
\text { Tanpa Flash }\end{array}$ & $\begin{array}{c}\text { Indoor } \\
\text { DenganFlash }\end{array}$ & $\begin{array}{c}\text { Outdoor } \\
\text { Tanpa Flash }\end{array}$ & $\begin{array}{c}\text { Outdoor } \\
\text { Dengan Flash }\end{array}$ \\
\hline 5 Megapiksel & Terdeteksi & Terdeteksi & Terdeteksi & Terdeteksi \\
\hline 8 Megapiksel & Terdeteksi & Terdeteksi & Terdeteksi & Terdeteksi \\
\hline 13 Megapiksel & Terdeteksi & Terdeteksi & Terdeteksi & Terdeteksi \\
\hline
\end{tabular}

- Warna yang diuji : Hitam Jenis kertas Foto

\begin{tabular}{|c|c|c|c|c|}
\hline Kamera & $\begin{array}{c}\text { Indoor } \\
\text { Tanpa Flash }\end{array}$ & $\begin{array}{c}\text { Indoor } \\
\text { DenganFlash }\end{array}$ & $\begin{array}{c}\text { Outdoor } \\
\text { Tanpa Flash }\end{array}$ & $\begin{array}{c}\text { Outdoor } \\
\text { Dengan Flash }\end{array}$ \\
\hline 5 Megapiksel & Terdeteksi & Terdeteksi & Terdeteksi & Terdeteksi \\
\hline 8 Megapiksel & Terdeteksi & Terdeteksi & Terdeteksi & Terdeteksi \\
\hline 13 Megapiksel & Terdeteksi & Terdeteksi & Terdeteksi & Terdeteksi \\
\hline
\end{tabular}

- Warna yang diuji : Putih Jenis kertas

\begin{tabular}{|c|c|c|c|c|}
\hline Kondisi & $\begin{array}{c}\text { Indoor } \\
\text { Tanpa Flash }\end{array}$ & $\begin{array}{c}\text { Indoor } \\
\text { DenganFlash }\end{array}$ & $\begin{array}{c}\text { Outdoor } \\
\text { Tanpa Flash }\end{array}$ & $\begin{array}{c}\text { Outdoor } \\
\text { Dengan Flash }\end{array}$ \\
\hline 5 Megapiksel & Tidak Terdeteksi & Tidak Terdeteksi & Tidak Terdeteksi & Tidak Terdeteksi \\
\hline 8 Megapiksel & Tidak Terdeteksi & Tidak Terdeteksi & Terdeteksi & Tidak Terdeteksi \\
\hline 13 Megapiksel & Tidak Terdeteksi & Tidak Terdeteksi & Terdeteksi & Terdeteksi \\
\hline
\end{tabular}

- Warna yang diuji : Putih Jenis kertas : Foto 


\begin{tabular}{|c|c|c|c|c|}
\hline Kondisi & $\begin{array}{c}\text { Indoor } \\
\text { Tanpa Flash }\end{array}$ & $\begin{array}{c}\text { Indoor } \\
\text { DenganFlash }\end{array}$ & $\begin{array}{c}\text { Outdoor } \\
\text { Tanpa Flash }\end{array}$ & $\begin{array}{c}\text { Outdoor } \\
\text { Dengan Flash }\end{array}$ \\
\hline 5 Megapiksel & Tidak Terdeteksi & Tidak Terdeteksi & Tidak Terdeteksi & Tidak Terdeteksi \\
\hline 8 Megapiksel & Tidak Terdeteksi & Tidak Terdeteksi & Terdeteksi & Tidak Terdeteksi \\
\hline 13 Megapiksel & Tidak Terdeteksi & Tidak Terdeteksi & Terdeteksi & Tidak Terdeteksi \\
\hline
\end{tabular}

\subsection{Analisis Pengujian}

Dari hasil pengujian yang telah didapatkan maka data tersebut dapat dianalisis berdasarkan spesifikasi kamera, tempat pengujian, penggunaan lampu flash dan media kertas yang digunakan yang ditampilkan pada tabel-tabel sebagai berikut :

Berdasarkan Spesifikasi Kamera

\begin{tabular}{|c|c|c|c|}
\hline $\begin{array}{c}\text { Spesifikasi } \\
\text { Kamera }\end{array}$ & $\begin{array}{c}\text { Jumlah } \\
\text { Keberhasilan }\end{array}$ & $\begin{array}{c}\text { Jumlah } \\
\text { Pengujian }\end{array}$ & $\begin{array}{c}\text { Persentase } \\
\text { Keberhasilan }\end{array}$ \\
\hline $5 \mathrm{MP}$ & 38 & 48 & $79,17 \%$ \\
\hline $8 \mathrm{MP}$ & 42 & 48 & $87,50 \%$ \\
\hline $13 \mathrm{MP}$ & 44 & 48 & $91,67 \%$ \\
\hline
\end{tabular}

Berdasarkan Tempat Pengujian

\begin{tabular}{|c|c|c|c||}
\hline Kondisi & $\begin{array}{c}\text { Jumlah } \\
\text { Keberhasilan }\end{array}$ & $\begin{array}{c}\text { Jumlah } \\
\text { Pengujian }\end{array}$ & $\begin{array}{c}\text { Persentase } \\
\text { Keberhasilan }\end{array}$ \\
\hline Indoor & 59 & 72 & $81,94 \%$ \\
\hline Outdoor & 65 & 72 & $90,28 \%$ \\
\hline
\end{tabular}

Berdasarkan Penggunaan Lampu Flash

\begin{tabular}{|c|c|c|c||}
\hline Kondisi & $\begin{array}{c}\text { Jumlah } \\
\text { Keberhasilan }\end{array}$ & $\begin{array}{c}\text { Jumlah } \\
\text { Pengujian }\end{array}$ & $\begin{array}{c}\text { Persentase } \\
\text { Keberhasilan }\end{array}$ \\
\hline Dengan Flash & 61 & 72 & $84,72 \%$ \\
\hline Tanpa Flash & 63 & 72 & $87,50 \%$ \\
\hline
\end{tabular}

Berdasarkan Media Kertas

\begin{tabular}{||c|c|c|c||}
\hline $\begin{array}{c}\text { Media } \\
\text { Objek }\end{array}$ & $\begin{array}{c}\text { Jumlah } \\
\text { Keberhasilan }\end{array}$ & $\begin{array}{c}\text { Jumlah } \\
\text { Pengujian }\end{array}$ & $\begin{array}{c}\text { Persentase } \\
\text { Keberhasilan }\end{array}$ \\
\hline HVS & 133 & 144 & $92,36 \%$ \\
\hline Photo Paper & 135 & 144 & $93,75 \%$ \\
\hline
\end{tabular}

\section{KESIMPULAN}

Kesimpulan yang dapat diambil berdasarkan hasil pengujian bahwa parameter yang mempengaruhi tingkat keakurasian dalam mengidentifikasi warna adalah spesifikasi kamera, cahaya dan media objek.

Semakin tinggi spesifikasi kamera yang digunakan maka semakin tinggi persentase keberhasilan yang diperoleh. Pengujian di luar ruangan (outdoor) memiliki persentase keberhasilan lebih tinggi dibandingkan dengan pengujian di dalam ruangan (indoor). Pengujian tanpa menggunakan lampu flash memiliki persentase keberhasilan lebih tinggi dibandingkan dengan menggunakan lampu flash. Dan, pengujian dengan media objek kertas Glossy Photo Paper memiliki 
persentase keberhasilan lebih tinggi dibandingkan ketika menggunakan media objek kertas Houtvrij Schrijfpapier (HVS).

Persentase keberhasilan aplikasi deteksi warna dalam mendeteksi warna mencapai 93,75\%.

\section{DAFTAR RUJUKAN}

[1] Cahyanti, M. Swedia, E.R. 2010. Algoritma Transformasi Ruang Warna. Bogor. Universitas Gunadarma.

[2] Frery.Alecandro C, Melo.C A S, Fernandes.R C. 2000. Web-based Interactive Dynamics for Color Models Learning. Brazil: Universidade Federal de Pernambuco Centra de Informatica.

[3] Greenacre, M. Primicerio, R. 2013. Multivariate Analysis of Ecological Data. Bilbao: Fundacion BBVA.

[4] Kumaseh, M.R. Latumakulita, L. Nainggolan, N. 2012. Segmentasi Citra Digital Ikan Menggunakan Metode Thresholding. Manado. Universitas Sam Ratulagi.

[5] Kurniawan, A. Ramadijanti, N. Saleh, A. 2010. Aplikasi Absensi Kuliah Berbasis Identifikasi Wajah Menggunakan Metode Gabor Wavelet. Surabaya. Institut Teknologi Sepuluh November.

[6] Kusumanto, R.D. Tompunu, A.N. 2011. Pengolahan Citra Digital Untuk Mendeteksi Obyek Menggunakan Pengolahan Warna Model Normalisasi RGB. Palembang. Politeknik Negeri Sriwijaya.

[7] Nafi'iyah, N. 2015. Algoritma Kohonen Dalam Mengubah Citra Graylevel Menjadi Citra Biner. Lamongan. Universitas Islam Lamongan.

[8] Ratabouil, S. 2015. Android NDK Beginner's Guide, Second Edition. Mumbai: PACKT Publishing.

[9] Samopa, F. Yulianawati. 2002. Penerapan Euclidean Distance Pada Pencocokan Pola Untuk Konversi Citra Ke Teks. Surabaya. Institut Teknologi Sepuluh November.

[10]Zharandont, P. 2015. Pengaruh Warna Bagi Suatu Produk dan Psikologis Manusia. Bandung. Universitas Telkom. 
MIND Journal | ISSN (p): 2528-0015 | ISSN (e): 2528-0902

DOI : https://doi.org/10.26760/mindjournal

| Vol. 3 | No. 1 | Halaman 37 - 48

[Juni] [2018] 